Vol 3 No 3 (2022) 450-456 P-ISSN 2620-295 E-ISSN 2747-0490

DOI: 1047467/elmal.v3i3.923

\title{
Pemanfaatan Sumber Daya Manusia Dalam Upaya Peningkatan Omset Penjualan
}

\author{
Muhammad Mumtaza Walad1, Meliyani'2, Sri Riska Ananda3 \\ Ahmad Alfarezzi ${ }^{4}$, Suhairi ${ }^{5}$ \\ Perbankan Syariah, Fakultas Ekonomi dan Bisnis Islam \\ Universitas Islam Negeri Sumatera Utara, Medan, Indonesia \\ mumtazaza741@gmail.com¹, yanimeli297@gmail.com², \\ sririskaanandalubis@gmail.com³ ${ }^{3}$ ahmadalfarezzi031@gmail.com ${ }^{4}$, \\ suhairi@uinsu.ac.id ${ }^{5}$
}

\begin{abstract}
Business development that occurs in the community is a very important factor, namely in terms of efforts to develop Human Resources (HR), among others, in terms of determining the price of a product that is traded, Promotion of products so that they sell well, maintaining product quality so that consumers do not disappointed, service so that consumers are satisfied and competitors who have an impact on sales results in the future.
\end{abstract}

Keywords : Development, Human Resources, Sales Turnover

\section{ABSTRAK}

Perkembangan usaha yang terjadi di tengah masyarakat merupakan faktor yang sangat penting yaitu dalam hal upaya pengembangan Sumber Daya Manusia (SDM) antara lain dalam hal penetapan harga atas sebuah produk yang di perjual belikan, Promosi terhadap produk agar laku terjual, menjaga Kualitas Produk agar konsumen tidak kecewa, Pelayanan sehingga konsumen puas dan Kompetitor yang mempunyai dampak pada hasil penjualan dimasa yang akan datang.

Kata Kunci : Perkembangan, Sumber Daya Manusia, Omset Penjualan

\section{PENDAHULUAN}

Sumber daya manusia adalah suatu hal yang sangat menentukan akan tercapainya suatu keberhasilan dalam suatu pelaksanaan dari kegiatan organisasi dalam kehidupan masyarakat. Hal yang menjadi tuntutan dalam klegiatan organisasi dengan tujuan untuk memperoleh, berupaya untuk mengembangkan serta mempertahankan sumber daya manusia yang berkualitas semakin susah didapatkan sesuai dengan perubahan lingkungan kehidupan masyarakat yang terus berubah. 


\section{Vol 3 No 3 (2022) 450-456 P-ISSN 2620-295 E-ISSN 2747-0490 DOI: 1047467/elmal.v3i3.923}

Pada saat sekarang ini kita lihat sumber daya manusia sangat dibutuhkan dalam upaya memajukan suatu Negara dari masa ke masa. Walaupun negara mempunyai sumber daya alam yang sangat melimpah ruah tapi kalau tidak ditompang atau didukung dengan sumber daya manusia yang berkualitas, negara tersebut tidak akan bisa maju.

Keberadaan sumber daya manusia adalah faktor yang sangat dibutuhkan baik secara pribadi ataupun kelompok masyarakat, dan sumber daya manusia merupakan sarana pengerak utama agar lancarnya suatu kegiatan dalam sebuah organisasi dalam masyarakat, bahkan maju maupun mundumya suatu usaha besar dipengaruhi oleh keberadaan sumber manusianya. Maka dari pada itu setiap usaha perlu menjadi perhatian dalam mengatur keberadaan karyawan sebagai usaha dalam meningkatkan kinerja usaha yang baik dari masa ke masa. Mengingat begitu pentingnya sumber daya manusia, maka perusahaan perlu memperhatikan karyawannya untuk disiplin dalam menjalankan tugas dan fungsinya disiplin dalam suatu pekerjaan merupakan kehendak dari setiap pekerja untuk memenuhi dan mematuhi segala peraturan yang berlaku, baik yang tertulis maupun tidak tertulis.

Pengembangan sumber daya manusia pada dasarnya adalah peningkatan kinerja pegawai yang mencerminkan kemampuan kerja anggota organisasi yang artinya kinerja setiap pegawai dievaluasi dan diukur sesuai standar yang ditetapkan oleh organisasi. Organisasi adalah sistem dan aktivitas kegiatan manusia yang salig bekerja sama. Sejalan dengan itu, organisasi dianggap mengkoordinasikan berbagai macam kegiatan untuk mencapai tujuan. Berdasarkan hal tersebut, organisasi mengharapkan pekerja untuk mencapai prestasi dan menciptakan kondisi yang menguntungkan baik untuk dirinya maupun perusahaan. Dengan cara ini karyawan tidak akan merasa jenuh, bosan, dan malas dalam bekerja sehingga menurunkan semangat kerja. Kinerja karyawan yang menurun dapat mengakibatkan kerugian organisasi.

Sumber Daya Manusia jika berpusat pada kompetensi harusnya dapat meningkatkan kapasitas dan juga dapat membangun dasar perusahaan sehingga apabila semua pekerja yang bekerja dalam suatu organisasi harus memiliki kemampuan yang tepat sesuai dengan apa yang menjadi tuntutan pekerjaannya, maka dia pastinya akan mampu baik itu dari segi pengetahuan pekerja, keterampilan pekerja maupun mental mental serta karakter produktifnya seorang pekerja. Jika kita melihat faktor motivasi dalam bekerja, kondisi tempat kerja para pekerja tersebut dalam melakukan aktivitas pekerjaan sehari - hari juga tidak kalah pentingnya dalam upaya untuk meningkatkan kinerja pekerja. Karena sesungguhnya lingkungan tempat kerja adalah kondisi utama serta psikologis yang pada sebuah lingkungan kerja. Lingkungan kerja yang baik dapat mendukung kegiatan kerja yang positif sehingga pekerja memiliki semangat dalam melakukan pekerjaan dan juga dapat meningkatkan kinerja para pekerjanya. 


\section{Vol 3 No 3 (2022) 450-456 P-ISSN 2620-295 E-ISSN 2747-0490 DOI: 1047467/elmal.v3i3.923}

Upaya peningkatan kualitas SDM yang berbasis pada target tertentu dilakukan supaya dapat menghasilkan apa yang diharapkan sesuai apa yang menjadi tujuan dan sasaran perusahaan dengan standar pekerjaan yang telah menjadi acuan untuk semua pekerja. Kompetensi menyangkut kewenangan setiap pihak dalam menjalankan tugas atau dalam pengambilan sebuah keputusan yang sesuai dengan peran setiap pekerja dalam perusahaan yang sesuai dengan keahlian, pengetahuan, dan kemampuan yang dimiliki oleh semua pekerjanya. Target dari seorang pekerja secara pribadi harus bisa mendukung pelaksanaan strategi perusahaan serta dapat mendukung setiap perubahan yang dilakukan perusahaan, dengan kata lain kompetensi yang dimiliki indivivual dapat mendukung sistem kerja berdasarkan tim yang saling bekerja sama.

Upaya dalam menciptakan kinerja yang tinggi, dibutuhkan adanya peningkatan kerja yang sesuai dan mampu memanfaatkan potensi Sumber Daya Manusia yang ada oleh setiap pekerja guna mencapai tujuan perusahaan, sehingga hal tersebut juga dapat memberi kontribusi yang positif bagi rencana perkembangan sebuah perusahaan ke arah yang lebih maju. Selain itu, organisasi perlu melihat berbagai faktor yang mungkin dapat mempengaruhi motivasi pekerja, dalam hal ini dirasa pelu adanya peran perusahaan dalam upaya meningkatkan motivasi serta menciptakan lingkungan kerja yang kondusif agar dapat mendorong terciptanya perilaku yang profesional dalam menyelesaikan pekerjaan sesuai dengan bidang dan tanggung jawab setiap pekerja.

\section{METODE PENELITIAN}

Bahan yang penulis pergunakan sebagai acuan dalam mengukur tingkat penilaian setiap alternative yang ada, seperti nama dari sebuah kriteria, tingkat kepentingan suatu kriteria terhadap kriteria lainnya dan rating kecocokan dalam upaya penilaian terhadap kriteria tersebut.

Penulis dalam melakukan penelitian ini adalah mennggunakan penggabungan dari dua metode yakni ; Tecnique For Order Preference by similiarity to ideal solution (TOPSIS) dan Borda. Metode TOPSIS dapat digunakan untuk menghitung setiap nilai dari suatu kriteria serta solusi dari masing-masing alternatif sehingga didapatkan rangking dari tiap lternatif solusi, Kemudian perhitungan di lanjutkan dengan metode Borda, dimana metode ini dapat di digunakan oleh para pengambil keputusan yang nantinya dapat memberikan penulis hasil aletrnatif atas solusi dari sebuah kegiatan dalam upaya penggambilan jalan terbaik dari pilihan beberapa alternatif yang ada. 


\section{Vol 3 No 3 (2022) 450-456 P-ISSN 2620-295 E-ISSN 2747-0490 DOI: 1047467/elmal.v3i3.923}

\section{HASIL DAN PEMBAHASAN}

Upaya meningkatkan Sumber Daya manusia adalah merupakan suatu proses yang digunakan untuk meningkatkan standar kualitas agar dapat menguasai pengetahuan, keterampilan, keahlian, dan wawasan yang sesuai dengan perkembangan ilmu pengetahuan dan teknologi, pada saat sekarang ini belum diterapkan sepenuhnya oleh sebagian UMKM yang ada di Indonesia. Adapun peningkatan pendapatan yang dapat dilakukan antara lain sebagai berikut:

\section{A. Pengetahuan}

Pengetahuan adalah merupakan salah satu dari upaya pengembangaan Sumber Daya Manusia. Pengetahuan adalah langkah-langkah karyawan untuk mengetahui dengan jelas bagaimana pekerjaannya, bagaimana dapat meningkatkan pekerjaannya dari waktu ke waktu, serta bagaimana pekerja mengetahui akan pekerjaannya dapat mempengaruhi omset penjualan srta penghasilan. Dalam peningkatan pengetahuan pekerja di sini, penjual ada baiknya mengadakan sesi pelatihan selain untuk mengasah kemampuan mereka juga dapat menambah pengetahuan mereka terhadap hal-hal yang berhubungan dengan pekerjaan.

\section{B. Keterampilan}

Peningkatan keterampilan merupakan suatu kemampuan seseorang dalam memanfaatkan akal, Pikiran, ide, dan kreativitas dalam mengerjakan, mengubah, ataupun membuat sesuatu menjadi lebih berguna sehingga dapat menghasilkan sebuah nilai dari pada pekerjaan tersebut. Dalam upaya pengembangan sumber daya manusia yang ada, keterampilan disini merupakan sesuatu yang dilatih dan dipraktikkan secara langsung.

C. Keahlian

Peningkatan keahlian adalah kecakapan yang dimiliki oleh pekerja, walaupun dalam konteks kesempatan kerja keahlian sering diartikan sebagai suatu kombinasi antara pengetahuan dan keterampilan tangan diantara pekerja. Dalam hal ini seluruh pengusaha pasti sangat menginginkan memiliki karyawan yang memiliki keahlian terutama dalam bidangnya. Untuk itu seharusnya ada suatu tempat khusus dan alat-alat yang disediakan perusahaan sebagai sarana khusus dalam upaya meningkatkan keahlian.

\section{Wawasan}

Wawasan adalah pandangan seseorang terhadap sesuatu hal berdasarkan apa yang diketahuinya. Wawasan dapat diperoleh dari orang lain, buku, film, dan pengalaman. Mempunyai wawasan yang banyak dapat membantu kita dalam mengambil keputusan dan berpikir positif terhadap banyak hal. Dalam hal 


\section{Vol 3 No 3 (2022) 450-456 P-ISSN 2620-295 E-ISSN 2747-0490 DOI: 1047467/elmal.v3i3.923}

peningkatan wawasan karyawan lebih kepada pengalaman karyawan selama bekerja bukan diajarkan melalui metode khusus dan untuk wawasan yang luas seperti pengetahuan terhadap semua bagian di perusahaan atau dalam hal ini UMKM, mereka memiliki wawasan sekedar ruang lingkup pekerjaan mereka saja. Pengembangan Sumber Daya Manusia (SDM) ini memiliki dampak pada omset penjualan rata-rata penurunan omzet penjualan yang sangat pesat terjadi padan bulan desember, terlihat perbedaan baik dari segi harga, cara pemasaran, kualitas, pelayanan, dan menghadapi competitor dapat dijelaskan sebagai berikut:

1. Penetapan Harga

Penetapan harga merupakan harga jual barang kepada konsumen yang merupakan harga jual produknya. Mengenai harga penjualan di produknya adalah rata-rata sama yaitu menetapkan misalnya harga sebesar Rp. 65.000,- tetapi ada beberapa toko yang pesaingdari produk sejenis menurunkan harga dengan harga menjadi Rp. 55.000 - Rp. 60.000 jika konsumen membeli dengan jumlah yang besar. Toko lain juga menerapkan hal yang sama. Perbedaan harga ini membedakan omset penjualan dari produsen satu dengan produsen lainnya karena ada pembeli atau konsumen yang melihat dari segi harga namun ada juga produsen yang menetapkan harga tinggi namun tidak mempengaruhi omset penjualan.

\section{Promosi Produk}

Promosi adalah pengenalan produk kepada calon konsumen agar mereka menjadi tertarik membeli produk dan pada akhirnya menjadi konsumen tetap. Promosi yang baik untuk memperkenalkan produk, mereka memiliki cara tersendiri yang berbeda-beda. Beberapa toko seperti Toko Nova mengenalkan produknya melalui penyebaran brosur kepada masyarakat sekitar kota medan dan mengenalkan produknya kepada kerabat dekat agar merekomendasikannya ke orang lain, promosi lewat jejaring sosial milik pribadi seperti lewat grup whatsapp, facebook dan instagram took yang dimiliki.

\section{Kualitas Produk}

Kualitas produk adalah suatu usaha untuk memenuhi atau melebihi harapan pelanggan, dimana suatu produk tersebut memiliki kualitas yang sesuai dengan standar kualitas yang telah ditentukan, dan kualitas merupakan kondisi yang selalu berubah karena selera atau harapan konsumen pada suatu produk selalu berubah.

4. Pelayanan

Pelayanan adalah proses pemenuhan kebutuhan melalui aktivitas orang lain secara langsung dan menolong menyediakan segala apa yang diperlukan orang lain, 


\section{Vol 3 No 3 (2022) 450-456 P-ISSN 2620-295 E-ISSN 2747-0490 DOI: 1047467/elmal.v3i3.923}

tamu atau pembeli. Pelayanan yang sopan dan juga ramah merupakan kunci pelayanan utama dari penjualan. Pelayanan yang baik ini tentu berimbas pada omset penjualan karena konsumen akan membeli jika salah satunya karyawan atau pemilik toko ramah, ketika di telfon melayani, serta adanya etika yang baik ketika menerima pesanan online.

\section{Menghadapi Pesaing/ Competitor}

Pesaing bisnis atau competitor merupakan salah satu hal yang ditakuti oleh sebagian pelaku usaha. Namun Gucyanana Flat Shoes tidak memandangnya seperti itu. Secara keseluruhan, pesaing bisnis dianggap sebagai motivasi untuk maju.

Berdasarkan penelitian yang dilakukan tim penulis secara keseluruhan, pengembangan kemampuan pekerja dalam upaya peningkatan pendapatan dari hasil penjualan masih jauh dari kata cukup. Hal ini karena jika kita melihat pada pemilihan karyawan yang dilakukan perusahaan tidak pernah memperhatikan keahlian, pendidikan, atau kemampuan pekerjanya sehingga pengusaha perlu mengajarkan pekerja dari dasar terlebih dahulu dalam upaya mengembangkan usahanya, melihat hal tersebut ada baiknya pengusaha atau perusahaan dalam mempekerjakan pekerja yang sudah berpengalaman atau memiliki keahlian tertetu atau setidaknya mempekerjakan pekerja khusus misalnya mereka yang ahli di bidang IT. Ini dapat dilakukan pengusaha guna mengatasi persaingan usaha yang semakin maju dalam mengikuti perkembangan zaman dan teknologi. Jika pemilik usaha tidak dapat bersaing maka secara otomatis omset dari usaha mereka tidak dapat meningkat dari tahun ke tahun atau bahka mengalami penuruan juga ditambah dengan upaya promosi, service, serta penigkatan kualitas produk yang dapat bersaing. Dalam hal persaingan antar para pelaku usaha maka para pelaku usaha juga dapat melakukan persaingan secara sehat dikarenakan dengan melakukan persaingan secara sehat maka tidak ada lagi antar sesama pesaing yang merasa dirugikan seperti halnya dalam upaya menjatuhkan harga pasar terhadap suatu produk.

\section{KESIMPULAN}

Upaya Peningkatan Kualitas dari SDM yang dipekerjakan dalam suatu usaha dengan tujuan untuk meningkatkan omset penjualan dapat bernilai negatif. Hal ini dapat dikarenakan karena banyak usaha tidak menerapkan pelatihan sesuai bidang pekerjaan yang akan diberikan kepada pekerjanya. Pengembangan kualitas sumber daya manusia dapat di mulai dari pengembangan terhadap bidang pekerjaan yang akan dipegang maka haruslah para pekerja memiliki pengetahuan, kemampuan, ahli, serta meningkatkan wawasan yang selama ini dirasa kurang mendapat perhatian. Mengenai omset pendapatan yang tidak stabil kadang naik dan turun lebih dipengaruhi oleh kualitas, cara pemasaran produk, dan pelayanan dari para pekerja 


\section{Cl, PIVIV | Jurnal Kajian Ekonomi \& Bisnis Islam \\ Vol 3 No 3 (2022) 450-456 P-ISSN 2620-295 E-ISSN 2747-0490 \\ DOI: 1047467/elmal.v3i3.923}

dimana hal tersebut tentu berhubungan juga dengan kualitas sumber daya manusia khususnya pekerja dalam suatu perusahaan atau lebih tepatnya usaha yang dijalani.

\section{DAFTAR PUSTAKA}

Etta Mamang S dan Sopiah, Perilaku Konsumen (Yogyakarta: PT. Bumi Aksara, 2013)

Hasibuan, Malayu S.P., Manajemen Sumber Daya Manusia (Edisi Revisi) (Jakarta: PT. Bumi Aksara, 2013)

Ketut Surya Diarta, Putu Widhianti Lestari dan Ida Ayu Putu Citra Dewi, "Strategi Branding dalam Promosi Penjualan Produk Pertanian Olahan PT. Hatten Bali untuk Pasar Pariwisata Indonesia", Jurnal Manajemen Bisnis, 2 (Oktober 2016).

Kotler, Philip, Manajemen Pemasaran Edisi Kesebelas (Jakarta: Penerbit Indeks, 2016)

Samsul Ma'arif, “Analisis Faktor-Faktor Yang Mempengaruhi Pendapatan Pedagang Pasar Bandarjo Ungaran Kabupaten Semarang". Jurusan Ekonomi Pembangunan Fakultas Ekonomi Universitas Negeri Semarang, 2013.

Sofyandi, Herman, Manajemen Sumber Daya Manusia (Yogyakarta: Graha Ilmu, 2013)

Teguh Triwiyanto, Nurul Ulfatin, Manajemen Sumber Daya Manusia Bidang Pendidikan (Jakarta: Rajawali Pers, 2016)

Thina Khuriyati, "Faktor-Faktor Penyebab Penurunan Omzet Penjualan Pada Industri Kerajinan Monel Di Desa Kriyan Kabupaten Jepara". Jurusan Teknologi Jasa Dan Produksi Fakultas Teknik Universitas Negeri Semarang, 2013. 